JOURNAL OF SECURITY AND SUSTAINABILITY ISSUES

ISSN 2029-7017 print/ISSN 2029-7025 online

2019 September Volume 9 Number 1

http://doi.org/10.9770/jssi.2019.9.1(16)

Scopus

\title{
PROCESS FACTORS OF SYSTEM SECURITY OF TRADING ENTERPRISES
}

\author{
Inga Shapovalova1, Ilona Piiurenko², Nataliia Husarina ${ }^{3}$, Svitlana Petrovska ${ }^{4}$, Marharyta Kravchenko ${ }^{5}$ \\ ${ }^{1 *}$ Mykolaiv Interregional Institute for Human Development, 2nd Viiskova Str., 22, Mykolayiv, 54003, Ukraine \\ ${ }^{2}$ Mykolaiv National Agrarian University, Georgiya Gongadze Str., 3 a, 54000 Mykolaiv, Ukraine \\ ${ }_{3}^{3}$ Kherson National Technical University, Beryslavske highway, 24, Kherson, 73008, Ukraine \\ ${ }^{4}$ National Aviation University, Komarova Avenue, 1, Kyiv, 02000, Ukraine \\ ${ }^{5}$ National University of the State Fiscal Service, street Universitetskaya, 31, Irpin, Kyiv region, 01000, Ukraine
}

E-mail: ${ }^{{ }^{*}}$ koaduep@gmail.com

Received 18 November 2018; accepted 20 June 2019; published 30 September 2019

\begin{abstract}
The scientific paper is devoted to the use of process factors of the functioning of trading enterprises in order to ensure their system security. The paper proposes a managerial algorithm for introducing the practice of standardization and certification in ensuring the safety of trade enterprises. It also proposes to introduce a process approach in the field of quality management and a process-logistic approach, which assesses the quality of the stages of the implementation of the trading processes in the enterprise. The paper proposes the calculation criteria and evaluation models.
\end{abstract}

Keywords: trading enterprise; system security; standardization and certification; quality management system; process approach; assessment models; market strategy

Reference to this paper should be made as follows: Shapovalova, I.; Piiurenko, I.; Husarina, N; Petrovska, S.; Kravchenko, M. 2019. Process factors of system security of trading enterprises, Journal of Security and Sustainability Issues 9(1): 211-255.

http://doi.org/10.9770/jssi.2019.9.1(16)

JEL Classifications: M 29; O 20

\section{Introduction}

One of the most significant events of the twentieth century is the service revolution, which is reflected in the expansion and substantial increase in the volume of the sales process, resulting in a qualitative change in the factors of economic development, sources of competitiveness of business entities and the structure of the aggregate income of the national economy, and in the direct participants in the sales process. Qualitative transformation of the trading process, strengthening its role in ensuring progressive macroeconomic dynamics and the spread of network forms of interaction between participants in trading activities led to the replacement of autonomous trading operators and open markets with international and national retailers, systematization of communications involving trade entities that affect the level and quality of the population life.

\section{Literature Survey}

A number of authors paid considerable attention to the management of trading enterprises (Colombelli, Quatraro, 2018; Douglas, et. al., 2016; Northouse, 2012; Tasnium, \& Singh, 2016; Mayorova et al., 2018) and issues of system security of business entities (Anthony, \& Govindarajan, 2000; Ravenswood, 2011; Xiang, et. al., 2018; Zemguliene, Valukonis, 2018; Masood et al., 2019; Davidavičienè et al., 2019). 
On the basis of these provisions, the studies on improving the efficiency of management of trading enterprises and the formation of a stable trend for the general security of their existence become relevant.

\section{Methods}

The purpose of this study is to provide scientific substantiation of the theoretical foundations and methodological approaches to improving the efficiency of trading enterprises and developing practical recommendations on the formation of their management system based on certification, quality management and compliance with trade standards.

\section{Results}

The instruments for ensuring such an important aspect of commercial activity as the quality of goods are standardization and certification. The procedure for carrying out standardization and certification establishes the following sequence of actions that make up the cumulative certification procedure.

1. Apply for certification. A trading company sends an application to the relevant certification body that examines the application within the established procedure for the certification of homogeneous products within a period of one month (on average one month) and informs the applicant of the decision, which, among the various information required by the applicant, indicates which authorities and test laboratories may select the applicant.

2. Sampling, identification of samples and their testing. Samples for testing are selected, as a rule, by a testing laboratory or other organization on its behalf. In some cases, this is done by the certification body. Samples that have been tested are stored for the period stipulated by the rules of the certification system for specific products. Test reports are submitted to the applicant by the certification organization, their storage corresponds to the validity period of the certificate.

3. Assessment of trading activities. Depending on the certification scheme chosen, an analysis of trading activity or a quality management system certification is carried out. The assessment method is indicated in the product conformity certificate.

4. Issuance of certificate of conformity. Test reports, assessment results of trading activities, other documents on product conformity, received by the certification body, are analyzed for a final understanding of product conformity with specified requirements (Abrhám, Lžicar, 2018; Akhmetova, Suleimenova, 2018).

5. Use of a mark of conformity. A trading company acquires the right to mark certified products with a mark of conformity by obtaining a license from the certification body. As a rule, each system has its own sign.

6. Inspection control over certified products is carried out if it is provided for by the certification scheme during the entire validity period of the certificate and license to use the mark of conformity (at least once a year). Form of control - periodic and unscheduled inspections with the testing of samples to prove that the presented products continue to meet the requirements, confirmed by certification.

The actions that are carried out by experts of the relevant certification body within these three components of the scheme are presented in table 1. 
Table 1. Schemes of standardization and certification in ensuring the security of trading enterprises

\begin{tabular}{|c|c|c|c|}
\hline pers & Verification of the trading process & $\begin{array}{c}\text { Inspection control } \\
\text { of certification } \\
\text { of the trading process }\end{array}$ \\
\hline 1 & $\begin{array}{c}\text { Assessment of the quality of the } \\
\text { performer of the trading process }\end{array}$ & Verification of the trading process result & $\begin{array}{c}\text { Quality control of the performer } \\
\text { and the trading process }\end{array}$ \\
\hline 2 & $\begin{array}{c}\text { Assessment of the process of performing } \\
\text { work, ensuring the trading process }\end{array}$ & Verification of the trading process result & $\begin{array}{c}\text { Process control of ensuring } \\
\text { the trading process }\end{array}$ \\
\hline 3 & Analysis of trading activities & Verification of the trading process result & Trade analysis \\
\hline 4 & Assessment of the trading enterprise & Verification of the trading process result & Compliance Control \\
\hline 5 & Quality System Assessment & Verification of the trading process result & Quality control system \\
\hline 6 & Control of permission documents & $\begin{array}{c}\text { Consideration of the declaration of compliance } \\
\text { with the documents that are attached }\end{array}$ & $\begin{array}{c}\text { Quality control of work } \\
\text { performance, ensuring the } \\
\text { trading process }\end{array}$ \\
\hline 7 & Quality System Assessment & $\begin{array}{c}\text { Consideration of the declaration of compliance } \\
\text { with the documents that are attached }\end{array}$ & Quality control system \\
\hline
\end{tabular}

Source: Bates, 2017

For certification of trading activities, as a rule, the following schemes are used: certification of the enterprise as a whole and the following inspection control; certification of the quality of service system and the next inspection control over their work (Drobyazko S., 2017; Drobyazko S., etc., 2019).

All indicators allowing to assess the effectiveness of the activities of a trading enterprise can be divided into three groups: process indicators, product indicators, customer satisfaction indicators.

The indicators of the process include the following groups of indicators (Tvaronavičienè, 2018):

- temporary indicators (duration of operation, performance, speed of completion of tasks);

- costs of scrap products (number of overdue products, number of returns, rejection in the pre-sales period, compensation payments to the consumer);

- financial and material expenses;

- training and advanced training costs;

- indicators of resource use per unit of output.

The indicators of a product (trading process) include the following groups of indicators:

- indicators that assess the level of product safety (trading process);

- indicators that assess the environmental friendliness of product (trading process);

- indicators that characterize product reliability (warranty period, number of defects, deviations from the declared level of quality, acceptable level of quality);

- functional indicators (number of product functions, range of product (trading process), comparison with analogues).

The methodology developed by us is based on the process and logistic approach, which is characterized by a set of indicators and a dynamic assessment of the effectiveness of the retail trade process. The process and logistic approach is based on an assessment of relative economic indicators, which make it possible to get an objective assessment for each trading process and an integral one throughout the trading enterprise. The process and logistic approach determines the use of a quality management system (QMS) (Korauš, et. al., 2019).

The implementation of quality management system insrtuments allows you to get a detailed assessment of the need to optimize the trading processes. Therefore, it is very important to analyze the trading process management system in order to obtain a decision on the need to implement a QMS and the effectiveness of its application. There are many approaches to assessing the effectiveness of the trading process system after the implementation of the QMS, which can be classified based on the indicators we have proposed (Table 2). 
Table 2. Classification of methodological approaches to assessment of the quality management system of a trading enterprise

\begin{tabular}{|c|c|}
\hline $\begin{array}{l}\text { Description of the methodological } \\
\text { approach }\end{array}$ & Description of the system of indicators and the procedure of their application \\
\hline $\begin{array}{l}\text { 1. Assessment using qualitative } \\
\text { indicators }\end{array}$ & $\begin{array}{l}\text { The efficiency and effectiveness of enterprise management is determined based on the } \\
\text { application of a scale of development levels from } 0 \text { to } 5 \text {. The level is determined based on the } \\
\text { applied management technologies, for which process characteristics are developed. }\end{array}$ \\
\hline \multirow[t]{2}{*}{$\begin{array}{l}\text { 2. Assessment using economic } \\
\text { indicators that characterize the } \\
\text { effectiveness of the implementation } \\
\text { of QMS in a trading enterprise }\end{array}$} & $\begin{array}{l}\text { The authors propose to assess the effectiveness and efficiency of processes using the following } \\
\text { indicators: } \\
\text { - degree of customer satisfaction; } \\
\text { - dynamics of growth in customer satisfaction; } \\
\text { - efficiency of the process (unit); } \\
\text { - level of quality } \mathrm{Q}=\mathrm{Cs}=\mathrm{Ki}(\mathrm{V} / \mathrm{C}), \\
\text { where } \mathrm{Q} \text { - product quality; } \\
C s \text { - customer satisfaction; } \\
K i \text { - enterprise image ratio; } \\
V \text { - value for the customer; } \\
C \text { - cost to customer. }\end{array}$ \\
\hline & $\begin{array}{l}\text { Assessment of efficiency of enterprises and retail trade based on the use of a generalized } \\
\text { indicator of resource returns. }\end{array}$ \\
\hline $\begin{array}{l}\text { 3. Cost method of assessing the } \\
\text { QMS in accordance with the cost } \\
\text { of implementation of the final } \\
\text { indicators }\end{array}$ & $\begin{array}{l}\text { The economic effect is determined using the growth rate of a certain predetermined indicator } \\
\text { for the year, and economic efficiency is calculated by comparing the growth rate of the indicator } \\
\text { with the costs that have been incurred for a certain period of implementation and operation of } \\
\text { the QMS. }\end{array}$ \\
\hline $\begin{array}{l}\text { 4. Combined method. Assessment } \\
\text { of the level of maturity of the QMS } \\
\text { with the calculation of the final } \\
\text { economic indicators }\end{array}$ & $\begin{array}{l}\text { The final index is determined based on customer satisfaction and economic performance of the } \\
\text { enterprise. }\end{array}$ \\
\hline \multirow[b]{2}{*}{ 5. Using expert methods } & $\begin{array}{l}\text { The effectiveness of the QMS is evaluated by four blocks of indicators: cost, natural, } \\
\text { appearance and reputation, and indicators of corporate culture. The experts assess the change in } \\
\text { indicators in each block, calculate the total contribution of all blocks of indicators in assessing } \\
\text { the effectiveness of implementing the QMS. }\end{array}$ \\
\hline & $\begin{array}{l}\text { a) An assessment of the effectiveness of the quality costs is carried out by comparing the } \\
\text { elements of costs, analyzing the proportion of elements in the overall quality costs structure, } \\
\text { comparison with other indicators of the organization. } \\
\text { b) The value of the effectiveness of the functioning of a commercial enterprise is determined by } \\
\text { the cumulative influence of individual components of the types of effectiveness. }\end{array}$ \\
\hline
\end{tabular}

Source: Copeland, 2001; Haque, et. al., 2019

In order to assess the effectiveness of the management of trading processes, we traditionally distinguish specific absolute indicators or characteristics that most fully reflect or describe the efficiency of trading processes of trade enterprises through the prism of three main indicators: productivity, costs, quality.

For trading enterprises, we identified three groups of consolidated trading processes: 1. purchase, 2. transportation and storage, 3. sale. In otder to assess the effectiveness of each group, we use its own group of relevant efficiency indicators. An assessment of the effectiveness of the implementation of the quality management system instruments taking into account the requirements of the ISO 9001 standard provides information on the performance of the trading process system (Hasanudin, et. al., 2019). For trading enterprises, one can distinguish the common components of these categories of expenses. They are presented in Table 3. 
Table 3. Cost components of standardization and functioning of the quality management system for trading enterprises

\begin{tabular}{|c|l|}
\hline $\begin{array}{c}\text { Cost category for quality } \\
\text { management systems }\end{array}$ & \multicolumn{1}{c|}{ Components } \\
\hline Costs for quality planning & $\begin{array}{l}\text { Costs for consultants; } \\
\text { Salary of the quality manager (if any); Costs for acquiring regulatory documents; } \\
\text { Part of salary of the top management of the organization (CEO and his deputies); } \\
\text { Costs for the implementation of management decisions related to the achievement of the goals of the } \\
\text { system. }\end{array}$ \\
\hline Costs for quality management & $\begin{array}{l}\text { Part of salary of managers of trading processes; Costs of bonuses related to the implementation of } \\
\text { goals in the field of quality. }\end{array}$ \\
\hline Costs for quality assurance & $\begin{array}{l}\text { Costs for additional equipment for monitoring and measurement required to meet the requirements } \\
\text { of internal regulatory documents; } \\
\text { Additional software costs; } \\
\text { Audit costs of management system of all stores of a trading enterprise. }\end{array}$ \\
\hline Costs for quality improvement & $\begin{array}{l}\text { Costs for the implementation of management decisions related to the implementation of corrective } \\
\text { and caution actions. }\end{array}$ \\
\hline
\end{tabular}

Source: Ho, \& Pollack, 2014

The development of trading enterprises with the use of innovative technologies has led to the development of a methodology for managing the efficiency of the trading process, consisting of a set of economic, managerial, social aggregates for optimizing resources, an author's approach to implementation of a quality management system, assessment of the effectiveness of the trading process and development (Delas, et. al., 2015). The methodical approach proposed in this study for assessment of the performance management of trading processes is presented in Fig. 1.

\begin{tabular}{|c|c|c|c|c|c|c|c|}
\hline & \multicolumn{5}{|c|}{$\begin{array}{l}\text { TYPES OF ECONOMIC ACTIVITY } \\
\text { OF THE TRADING ENTERPRISE (EA) }\end{array}$} & \\
\hline & & Procuring $(\mathrm{P})$ & $\begin{array}{l}\text { Trading and } \\
\text { Operational } \\
\quad(\mathrm{T})\end{array}$ & $\begin{array}{c}\text { Managerial } \\
\text { (M) }\end{array}$ & $\begin{array}{c}\text { Other } \\
\text { (I) }\end{array}$ & $\begin{array}{l}\text { Total by } \\
\text { types of } \\
\text { economic } \\
\text { activity } \\
\text { (TT) }\end{array}$ & \\
\hline \multirow{4}{*}{$\begin{array}{c}\text { EFFICIENCY } \\
\text { CHARACTERISTICS } \\
\text { (E) }\end{array}$} & Performance $(\mathrm{P})$ & $P_{p}$ & $P_{T}$ & $\mathrm{P}_{\mathrm{M}}$ & $P_{i}$ & $\mathrm{P}_{\mathrm{TT}}$ & \multirow{3}{*}{$\begin{array}{c}\text { EFFICIENCY } \\
\text { OF ECONOMIC } \\
\text { ACTIVITY } \\
\text { OF TRADING } \\
\text { ENTERPRISE } \\
\text { TOTAL BY } \\
\text { CHARACTERISTICS }\end{array}$} \\
\hline & Effectiveness (EF) & $\mathrm{EF}_{\mathrm{P}}$ & $\mathrm{EF}_{\mathrm{T}}$ & $\mathrm{EF}_{\mathrm{M}}$ & $\mathrm{EF}_{\mathrm{i}}$ & $\mathrm{EF}_{\mathrm{TT}}$ & \\
\hline & Optimality (OPT) & $\mathrm{OPT}_{\mathrm{P}}$ & $\mathrm{OPT}_{\mathrm{T}}$ & $\mathrm{OPT}_{\mathrm{M}}$ & $\mathrm{OPT}_{\mathrm{i}}$ & $\mathrm{OPT}_{\mathrm{TT}}$ & \\
\hline & Total characteristics & $\mathrm{E}_{\mathrm{p}}$ & $\mathrm{E}_{\mathrm{T}}$ & $\mathrm{E}_{\mathrm{M}}$ & \multirow[t]{2}{*}{$\mathrm{E}_{\mathrm{i}}$} & & \\
\hline & & \multicolumn{3}{|c|}{$\begin{array}{c}\text { EFFICIENCY OF TOTAL BY TYPES } \\
\text { OF ECONOMIC ACTIVITY } \\
\text { OF TRADING ENTERPRISE }\end{array}$} & & & \\
\hline
\end{tabular}

Fig. 1. Methodical approach to a complex assessment of the effectiveness of the trading process based on a systematic approach

Source: Designed by the authors

The main aim of this approach is to improve the management system of a trading enterprise. At the first stage, objectives in the field of quality by processes are formed and an appropriate assessment and analysis are carried out. Within this algorithm, a matrix of effectiveness and efficiency of processes is formed, appropriate management decisions are developed. Next, the implementation process, controlling and monitoring, as well as the development of actions for adjustment are carried out. It is important to note that the main aim of this methodology is to provide conditions for increasing the efficiency of the trading process and developing practical recommendations on how to form efficiency (Bengtsson, 2001). 
The conducted study of theoretical and methodological developments allowed to formulate and test the methodology for assessing the effectiveness of the trading process on the basis of a systematic approach. The author found that in managing the efficiency of the enterprise's trading process, its assessment is an important application of the process approach, which is the most effective way of organizing and managing in order to create value for the trading process for consumers and owners.

The main distinctive feature of this methodology from the existing ones is the use of quantitative relative indicators, which allow an objective assessment of the effectiveness. In addition, the assessment is based on a system of criteria for trading processes, so you can see the strengths and weaknesses of a particular process and develop appropriate recommendations. Dynamic evaluation of the effectiveness of the trading process with the proposed methodology allows us to determine the picture of the development of a trading enterprise in comparison with its competitors.

The proposed methodology for the process and logistic approach of the assessment includes the first block of the following steps:

1. selection of trading processes in the activities of the organization and their description.

2. development of a system of indicators to measure the effectiveness of each business process.

3. assessment of trading processes and the development of measures to adjust the management system.

Let's consider a possible system of indicators based on the process-logistic approach to ensuring the secuity of economic activity. In the course of the study, a methodology was developed for assessment of the effectiveness of trading enterprises using a process and logistic approach and taking into account customer preferences.

Taking into account the fact that in the studies devoted to evaluating the effectiveness of a trading enterprise on the basis of a process and logistic approach, recommendations for improving trading processes are more presented, we will single out specific financial indicators characterizing, in our opinion, the efficiency of most trading processes.

The proposed methodology is based on a comparative assessment of the significant stages of the implementation of trading processes. Let's consider the indicators included in the system (according to (Kislingerová, 2007; Ehrenberger, et. al., 2015).

1. Product mix width - is the number of product groups of goods, characterized by a coefficient of width $\left(K_{w}\right)$ :

$$
K_{w}=\frac{G_{f}}{G_{n}}
$$

where $G_{f}$ - number of product groups of goods at the time of determination, units; $G_{f n}$ - total number of product groups of goods, units.

2. Completeness of the product assortment is the ratio of the actual availability of types of products to the existing assortment list, effective demand.

Completeness of the product assortment is expressed through the coefficient of completeness of the product assortment $K_{n}$, which is determined by the formula:

$$
K_{n}=\frac{V_{f}}{V_{n}}
$$

where $V_{f}$-actual number of types of products at the time of inspection (verification), units;

$V_{n}$ - number of types provided by the assortment list, supply agreement, standards, etc., units. 
3. Depth of the assortment is the number of types of products for each item. The coefficient of the depth of the assortment $\left(K_{d}\right)$ is calculated by the formula:

$$
K_{d}=\frac{R_{f}}{R_{n}}
$$

where $R_{f}$-actual number of types of products at the time of inspection, units;

$R_{f n}-$ number of types provided by the assortment list, supply agreement, price-list, etc.

4. Coefficient of novelty of the product assortment is the ratio of the number of new products to the total number of items of products (or current width $-W_{n}$ ):

$$
W_{n}=\frac{N}{S_{d}}
$$

where $\mathrm{N}$ - number of new products;

$S_{d}-$ total number of types, varieties and names of products of the same homogeneous groups.

5. Rationality of the assortment is described by the coefficient of rationality $\left(K_{r}\right)$, which is determined as the weighted average of the indicator of rationality, taking into account the values of indicators of width, completeness, sustainability and novelty, taking into account the coefficients of significance of each indicator $\left(V_{w}, V_{n}\right.$, $\left.V_{d}, V_{n}\right)$. The coefficients of significance are determined by an expert, reflecting the proportion of each indicator in customer preferences, affecting the sale of goods. The coefficients of significance have values from 0 to 1.

$$
K_{r}=\frac{K_{w} \times \mathrm{V}_{w}+\mathrm{K}_{n} \times \mathrm{V}_{n}+\mathrm{K}_{d} \times \mathrm{V}_{d}+W_{n} \times \mathrm{V}_{n}}{4}
$$

6. Coefficient of uniformity of input of products is the ratio of products, which arrived in time according to plan, to the total amount of input of products:

$$
K_{\text {mid }}=\frac{A V_{p}}{A V_{s}}
$$

where $A V_{p}$ - products, which arrived in time according to plan;

$A V_{s}^{p}-$ total amount of input of products.

7. The coefficient of change in logistics costs per unit of turnover is the ratio of the change in the amount of logistics costs for turnover:

$$
K_{c h}=\frac{\left(\mathrm{CH}_{1}-\mathrm{CH}_{0}\right)}{T_{o}}
$$

In continuation of these studies, we can provide a list of the main and defining indicators that determine the effectiveness of trading processes at a trading enterprise (Table 4). 
Table 4. Indicators that determine the effectiveness of trading processes at a trading enterprise

\begin{tabular}{|c|c|c|}
\hline Name of the trading process & Operations & $\begin{array}{l}\text { Indicators for assessing the level } \\
\text { of implementation of trading processes }\end{array}$ \\
\hline \multirow{5}{*}{$\begin{array}{c}\text { Procurement, supply management } \\
\text { of products that are sold, pre-sales } \\
\text { service }\end{array}$} & $\begin{array}{l}\text { management of } \\
\text { procurement activities }\end{array}$ & Coefficient of novelty of the product assortment \\
\hline & assortment policy & Product mix width \\
\hline & $\begin{array}{l}\text { market and supplier } \\
\text { effectiveness analysis }\end{array}$ & Coefficient of completeness of the product assortment \\
\hline & order management & Coefficient of rationality, level of service delivery \\
\hline & $\begin{array}{l}\text { product distribution } \\
\text { policy }\end{array}$ & Coefficient of uniformity of input of products \\
\hline \multirow{3}{*}{ Logistics of assortment flow } & acceptance of the goods & $\begin{array}{l}\text { labor productivity of employees of the distribution center } \\
\text { (warehousing); coefficient of use of warehouse space }\end{array}$ \\
\hline & warehousing and storage & coefficient of logistic costs change per unit of turnover \\
\hline & $\begin{array}{l}\text { pre-sale preparation of } \\
\text { products (unpacking, } \\
\text { sorting, marking) }\end{array}$ & coefficient of turnover of the cargo \\
\hline \multirow{5}{*}{ Sales management } & inventory management & $\begin{array}{l}\text { level of customer service, coefficient of change of one-day } \\
\text { turnover of a trading enterprise }\end{array}$ \\
\hline & merchandising & coefficient of change of the average purchase amount \\
\hline & $\begin{array}{l}\text { organization } \\
\text { of retail sales }\end{array}$ & coefficient of change in retail sales per 1 sq. $\mathrm{m}$ of retail space \\
\hline & sale & share of advertising costs in costs, level of staff turnover \\
\hline & $\begin{array}{l}\text { customer service, } \\
\text { promotion of goods }\end{array}$ & $\begin{array}{l}\text { share of additional profit obtained through sales promotion, ratio } \\
\text { of the average wage per salesperson to personnel training costs }\end{array}$ \\
\hline
\end{tabular}

Source: Designed by the authors

The first block for the assessment of the effectiveness of the trading process based on the process-logistic and client-oriented approaches is presented in Fig.2.

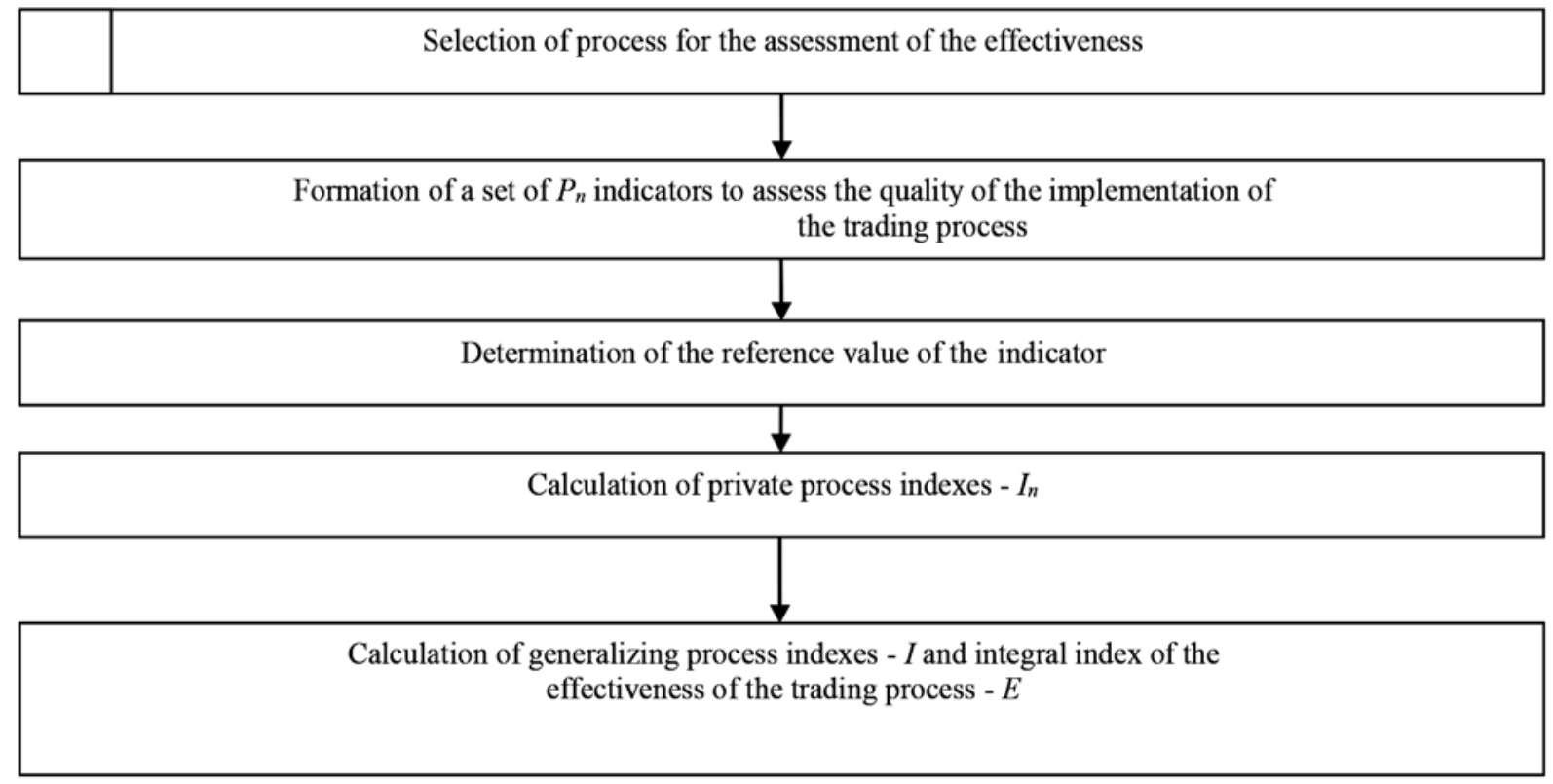

Fig. 2. I block - methodology for assessing the effectiveness of the trading process based on

Source: Designed by the authors

1 stage. Selection of process for the assessment of the effectiveness. 
2 stage. Formation of a set of $P_{n}$ indicators to assess the quality of the implementation of the trading process. At this stage, a matrix of initial data is compiled. The form of presentation of the matrix of initial data, where indicators are systematized to assess the implementation of business plans (Fig. 3).

\begin{tabular}{|c|l|l|l|l|l|l|l|l|}
\hline \multirow{2}{*}{ Number of indicators } & \multicolumn{5}{|c|}{ Trading networks (enterprises) } \\
\hline & & & & & & & & \\
\hline 1 & & & & & & & & \\
\hline 2 & & & & & & & & \\
\hline. & & & & & & & & \\
\hline .. & & & & & & & & \\
\hline $\mathrm{I}$ & & & & & & & & \\
\hline
\end{tabular}

Fig. 3. Matrix of initial data on the quality assessment of the implementation of the trading process

Source: Designed by the authors

Assessment indicators are presented along with their reference value.

3 stage. Determination of the reference value of the indicator. The establishment of a reference criterion is based on the best indicators possible in the implementation of this trading process. For each indicator, the best (max) value is calculated and entered into the relative reference value column $a_{i e}$.

4 stage. Calculation of private trading process indexes $-I_{n}$. It includes standardization $a_{i j}$ in relation to the reference $a_{i e}$ :

$$
\mathrm{P}_{\mathrm{ij}}={\frac{a_{\mathrm{ij}}}{a_{i e}}}_{e}
$$

where $a_{i j}$-standardized indicators of the state of the $\mathrm{j}$-th trading enterprise.

The ideal value is 1 .

Thus, the basis for the assessment is the state of affairs of a trading enterprise that have emerged as high results from the entire set of compared objects. As a result, with this assessment approach, every trading enterprise strives to be the best (Kumara, Ramachandranb, 2016).

5 stage. Calculation of generalizing process indexes $-I$ and integral index of the effectiveness of the trading process $-E$.

A generalizing indicator for assessment of the effectiveness of each trading process is determined as an arithmetic average of private standard indicators $\left(P_{n}\right)$ :

$$
I=\frac{1}{N} \times \sum_{n=1}^{N} I_{n}
$$

where $I$ - generalizing indicator for assessment of the effectiveness of each trading process; $N$ - number of private standard indicators of the quality of the process implementation.

The integral indicator of the efficiency of the enterprise's trading process is calculated as the formation of three generalizing indices of trading processes based on the process and logistic approach: 


$$
E=I_{1} \times I_{2} \times I_{3}
$$

Then the integral indicator of the efficiency of the trading process is calculated for a number of competing retail chains. The higher its own integral index is, the more it speaks about the effectiveness of the activities of the trading enterprise under study (Muradl, Ahmadov, 2019).

The advantage of the presented author's methodology is based on the availability of a quantitative assessment of the level of implementation of trading processes, which allows to accurately determine the degree of its effectiveness. Using the presented algorithm allows us to simplify the assessment of decisions when choosing the right strategy for the development of a trading enterprise (Makedon, et. al., 2019b).

The adoption of management decisions based on the results of the analysis in order to improve the efficiency of trading processes, first, requires clarification of the influence factors. Secondly, it is necessary to carry out a whole range of measures that will improve the importance of each indicator characterizing this trading process and will produce a positive result in general. Thus, for the growth of the value of the coefficients of width and novelty of assortment, you need to constantly revise the assortment of trading enterprises; select groups of products that are not in demand, withdraw them from the nomenclature, replacing them with more attractive products for the customer. In this case, you can use the ABC-analysis. In order to increase the uniformity of supply of goods, it is necessary to adjust the relationship with suppliers, it is necessary to establish a procurement system on the principle of "just in time" and correlate the volumes of stocks to the current sales volumes.

II block - methodology for assessing the effectiveness of trading enterprise security management based on the use of QMS instruments.

1. It consists of the following stages (Cherry, 2007):

2. Analysis of the maturity levels of the management system of the trading enterprise.

3. Assessment of the resulting economic indicator.

4. Determination of the position of the trading company in the matrix of the development of the trading process.

5. Determination of the feasibility or inappropriateness of implementing a quality management system to ensure the effectiveness of the trading process.

The author analyzed the level of maturity of the trading enterprise management system based on the self-assessment methodology, compiled in accordance with ISO 9004, but approved to the requirements of ISO 9001 and the specifics of the functioning of trading enterprises based on the implementation of a quality management system. At the same time, the level of maturity was carried out on the basis of the process approach by an expert method. Therefore, criteria were developed for each process of the trading enterprise according to the appropriate levels of maturity. The overall level of maturity of the system will be determined by level, on average for most processes.

It is important to note that a distinctive feature of this technique is that it applies to almost all processes of the organization of the trading process. The second feature is the application of the project approach in the implementation of the quality management system, which allowed the construction of a performance management system for the trading process without using the functional approach and the ISO standard, which are usually used by consulting organizations (Makedon, et. al., 2019a).

A system of criteria is selected under each trading process of a trading enterprise according to 5 levels of development. These are indicators that characterize the maturity of each trading process (the minimum requirements apply to the 1st level of development, the maximum, according to the ISO 9004 standard - the 5th level). The level of development of the entire management system is defined as the arithmetic average value of the development of all processes of an enterprise. Determining the requirements for the level of development of the management system allows us to select the actions necessary to transfer each process of the trading enterprise to the next level of development. 
The methodology for assessment of the trading process system based on QMS as an innovative instrument to ensure the effectiveness of the trading process includes the following steps:

- assessment of the development of retail chain management system in general;

- calculation of the effectiveness of trading activities;

- determination of the position of the trading company in the matrix of the development of the trading process;

- conclusions on the feasibility of using a quality management system to develop the trading company.

It has been proposed to assess the development of the retail network management system as a whole using the self-assessment methodology described in the ISO 9004 standard, but adapted to the requirements of the ISO 9001 standard and taking into account the characteristics of the trading enterprises. The level of development of a retail distribution network management system is assessed on the basis of a process approach with the involvement of experts Kordík, Kurilovská, (2019).

III block - analysis of trading process management system. It is carried out by calculating the effectiveness of trading activities, reflects the dynamics of the effectiveness of its development. Such a key resulting indicator for trading enterprises proposed to use the annual increase in turnover.

In order to determine the position of a trading company in the system of two coordinates, "quality of activity the level of maturity of the management system" - "integral indicator of the efficiency of the trading process": (Figure 4) it was proposed to use a matrix consisting of four areas:

1. low level of efficiency of the trading process $(\mathrm{E} \leq 0,4)$, weak level of management system development, low economic efficiency (area $A$ );

2. middle level of efficiency of the trading process $(0,41 \leq \mathrm{E} \leq 0,6)$, medium level of management system development, low economic efficiency $(\operatorname{area} B)$;

3. middle level of efficiency of the trading process $(0,41 \leq \mathrm{E} \leq 0,6)$, low level of management system development, high economic efficiency (area $D$ );

4. high level of efficiency of the trading process $(E \geq 0,61)$, highly professional development of management system (area C), high economic efficiency.

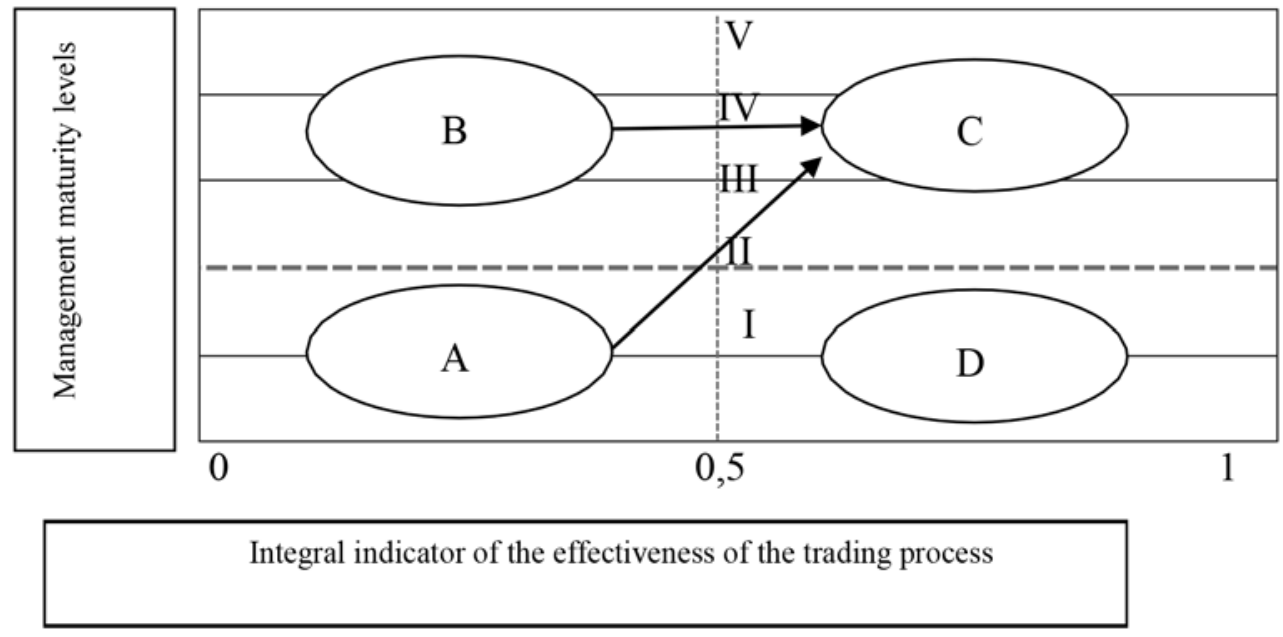

Fig. 4. Matrix of the development of the trading process

Source: Designed by the authors

Retail chains that fall into area A should strive to increase their efficiency, or they have the risk of losing their business and leaving the market. Regarding the use of possible innovations, a strategy of imitative development is applicable - a low level of intensive development. Further actions of the trading enterprise management within the framework of the strategy are reduced to the fact that the retail distribution network borrows 
(duplicates) innovations implementation for the purpose of intensive development (Limba, Šidlauskas, 2018). This strategy can be effective in cases where the trading network is far behind competitors or develops a new format of trade.

\section{Discussion}

The enterprises entering the area B have a developed management system, but low turnover. A similar situation can be a consequence of high competition in the market or because the organization has recently entered a new market for itself. The strategy of survival with such a position will be to increase the client base, the formation of loyal customer, improvement of the quality of service and assortment. In this case, the simulation strategy is applicable or the result is saved.

For trading enterprises that have a position in the region of $\mathrm{C}$, it is necessary to maintain the achieved advantage, the adopted strategy of development, the developed regulation in the management system. Such enterprises do not require a change in the management system. It is required from time to time to initiate self-examination of the management system to detect a negative change in occupied position. It is advisable to use a strategy to preserve the achieved positions.

The position of the organization in the field of $\mathrm{D}$ with high values of economic indicators indicates that its sphere of activity, the niche of the market, which it occupies, is not yet occupied and not mastered by competitors. The low level of competition allows a trading company to flourish with a weakly developed management level. However, with increasing competition, trade turnover will be higher among companies with strong management. They will be able to better satisfy the client. Therefore, in the long run, implementation of a quality management system is required, which allows for a high level of trade turnover (Protogerou, et. al., 2017).

Trading enterprises that fall in areas A and B must, through the formation of a quality management system in the provision of the trading process, move to area $\mathrm{C}$, since they have a very low increase in turnover.

The proposed method of self-assessment of the position of a trading enterprise allows you to determine the actions that are needed to move to the next level of development. If the trading enterprise decided to improve on the basis of the quality management system, the top management, based on the development levels, will set goals that allow the trading enterprise to improve. In order to achieve these goals, we need certain costs, which we called the costs for the quality management system. The effectiveness of the development of trade network management using the quality management system will be determined on the basis of an assessment of the degree of achievement of goals, and efficiency - on the basis of costs.

\section{Conclusions}

Thus, we can state that it was justified that the efficiency of the trading process is determined not only by economic indicators of enterprises' economic activities, but also indicators of the effectiveness of certification, standardization and customer-oriented organization. The author proposed a methodology for a systematic approach to evaluating the effectiveness of the trading process.

The category of efficiency of the enterprise's trading process as a result of entrepreneurial activity has been clarified; it is achieved through the rational use of resources at each stage of the process, while ensuring customer-oriented staff and consumers.

The method proposed by us, based on the application of the system approach, allows retailers to more fully and objectively assess the measures taken to improve their activities from different perspectives: quality indicators, classification of assortment and quantitative indicators (financial and economic performance). 
The substantiation of the need to implement a quality management system (QMS), planning work on the development of QMS documentation, development of technical specifications for the design of QMS; project development of QMS documents; preparation of the schedule of implementation in the activities of a commercial enterprise; monitoring and measuring the quality of functioning, improving the QMS by making changes and finalizing the documentation was carried out.

A matrix for the development of the trading process has been proposed, which gives an assessment of the positioning of the trading enterprise and determines the development strategy, the choice of possible innovations and innovative technologies that will ensure the efficiency and security of trading processes.

\section{References}

Abrhám, J., Lžicar, P. (2018). Risk management in the sustainable development: analysis of a selected key industry. Journal of Security and Sustainability Issues, 8(2), 171-180. https://doi.org/10.9770/jssi.2018.8.2(5)

Akhmetova, S. O., Suleimenova, M.S. 2018. Quality management system for improvement of quality and efficiency of food production: case of dairy products enterprise. Enterpreneurship and Sustainability Issues, 6(1), 289-310. http://doi.org/10.9770/jesi.2018.6.1(18)

Anthony, R. N., \& Govindarajan, V. (2000). Management control systems (12th edn.). Boston: McGraw-Hill.

Bates, R. (2017). The Development Dilemma: Security, Prosperity, and a Return to History. Princeton University Press, p.200.

Bengtsson, J. (2001). Manufacturing flexibility and real options: A review. International Journal of Production Economics, 74(1-3), 213-224. https://doi.org/10.1016/S0925-5273(01)00128-1

Colombelli, A., Quatraro, F. (2018). New firm formation and regional knowledge production modes: Italian evidence. Research Policy, 47(1), 139-157. https://doi.org/10.1016/j.respol.2017.10.006

Copeland, T. (2001). Real Options Analysis. Texere Publishing, New York.

Cherry, H. (2007). Financial Economics. 1st edition. Actuarial Study Materials, 3217 Wynsum Ave., Merrick, NY 11566. https://doi. org/10.5251/ajsms.2010.1.1.67.74

Davidavičienė, V., Raudeliūnienė, J., Tvaronavičienė, M., Kaušinis, J. (2019). The importance of security aspects in consumer preferences in electronic environment. Journal of Security and Sustainability Issues, 8(3), 399-411. http://doi.org/10.9770/jssi.2019.8.3(9)

Delas, V., Nosova, E., \& Yafinovych, O. (2015). Financial security of enterprises. Procedia Economics and Finance, 27, 248-266. http:// doi.org/10.1016/S2212-5671(15)00998-3

Douglas, A., Shahid, B., \& Shows, D. (2016). Customer-salespeople relationship: Influence of sales people entrepreneurial behaviours. Marketing Intelligence \& Planning, 34, 5, 586-604. http://doi.org/10.1108/MIP-09-2015-0170

Drobyazko S. (2017). Formation of competitive positions as providing of economic security of insurance companies. International scientific journal “Internauka”. Series: “Economic Sciences”, №2. URL: https://doi.org/10.25313/2520-2294-2017-2-4784

Drobyazko S., Hryhoruk I., Pavlova H., Volchanska V., Sergiychuk S. (2019). Entrepreneurship innovation model for telecommunications enterprises. Journal of Entrepreneurship Education, 22(2) URL: https://www.abacademies.org/articles/entrepreneurship-innovation-model-for-telecommunications-enterprises-8097.html

Ehrenberger, M., Koudelkova, P., Strielkowski, W. (2015). Factors influencing innovation in small and medium enterprises in the Czech Republic. Periodica Polytechnica Social and Management Sciences 23(2):73-83. https://doi.org/10.3311/PPso.7737

Hasanudin, A.I., Yuliansyah, Y., Said, J., Susilowati, Ch., Muafi. (2019). Management control system, corporate social responsibility, and firm performance, Entrepreneurship and Sustainability Issues, 6(3), 1354-1368. http://doi.org/10.9770/jesi.2019.6.3(21)

Haque, A. U., Kot, S., Imran, M. (2019). The moderating role of environmental disaster in relation to microfinance's non-financial services and women's microenterprise sustainability. Journal of Security and Sustainability Issues, 8(3), 355-373. http://doi.org/10.9770/ jssi.2019.8.3(6)

Ho, V., \& Pollack, J. (2014). Passion isn't always a good thing: Examining entrepreneur's network centrality and financial performance with a Dualistic Model of Passion. Journal of Management Studies, 51(3), 433-459. http://doi.org/10.1111/joms.12062 
Kislingerová, E. (2007). Manažerské finance [Managerial Finance]. Praha: C.H.BECK.

Kordík M. Kurilovská, L. (2019). Content of a IntraGroup Compliance Agreement as a risk mitigating factor. Entrepreneurship and Sustainability Issues, 6(3), 1195-1204. http://doi.org/10.9770/jesi.2019.6.3(10)

Korauš, A., Dobrovič, J., Polák, J., Kelemen, P. (2019). Security position and detection of unusual business operations from science and research perspective. Entrepreneurship and Sustainability Issues, 6(3), 1270-1279. http://doi.org/10.9770/jesi.2019.6.3(15)

Kumara, R.; Ramachandranb, P. (2016). Revenue management in remanufacturing: perspectives, review of current literature and research directions. International Journal of Production Research, 54(7), 2185-2200. https://doi.org/10.1080/00207543.2016.1141255

Limba, T., Šidlauskas, A. (2018). Secure personal data administration in the social networks: the case of voluntary sharing of personal data on the Facebook. Entrepreneurship and Sustainability Issues, 5(3), 528-541. https://doi.org/10.9770/jesi.2018.5.3(9)

Makedon, V., Drobyazko, S., Shevtsova, H., Maslosh, O., Kasatkina, M. (2019a). Providing security for the development of hightechnology organizations. Journal of Security and Sustainability Issues, 8(4), 1313-1331. http://doi.org/10.9770/jssi.2019.8.4(18)

Makedon, V., Hetman, O., Yemchuk, L., Paranytsia, N., Petrovska, S. (2019b). Human resource management for secure and sustainable development. Journal of Security and Sustainability Issues, 8(3), 345-354. http://doi.org/10.9770/jssi.2019.8.3(5)

Masood, O., Tvaronavičienè, M., Javaria, K. (2019). Impact of oil prices on stock return: evidence from G7 countries. Insights into Regional Development, 1(2), 129-137. https://doi.org/10.9770/ird.2019.1.2(4)

Mayorova, A.N., Panasenko, S.V., Nikishin, A.F., Ivanov, G.G., Mayorova, E.A. 2018. Analyzing regional differences in the condition and development of trade in Russia. Entrepreneurship and Sustainability Issues, 6(2), 927-938. http://doi.org/10.9770/jesi.2018.6.2(30)

Muradl, N., Ahmadov, F. (2019). Managing contradiction and sustaining sustainability in inter organizational networks through leadership: A case study. Entrepreneurship and Sustainability Issues, 6(3): 1255-1269. http://doi.org/10.9770/jesi.2019.6.3(14)

Northouse, P. G. (2012). Leadership: Theory and Practice. 6th ed.; NY, U.S: Sage Publications, p. 236

Protogerou, A., Caloghirou, Y., Vonortas, S.N. (2017). Determinants of young firms' innovative performance: Empirical evidence from Europe. Research Policy, 46(7), 1312-1326. https://doi.org/10.1016/j.respol.2017.05.011

Ravenswood, K. (2011). Eisenhardt's impact on theory in case study research. Journal of Business Research, 64(7), 680-686. https:// doi.org/10.1016/j.jbusres.2010.08.014

Tasnium, R., \& Singh, H. (2016). What, exactly, is entrepreneurial commitment? Journal of Applied Management and Entrepreneurship, 21, 3, 6-35. https://doi.org/10.9774/GLEAF.3709.2016.ju.00003

Tvaronavičienè, M. (2018). Elaborating internationally tuned approach towards critical infrastructure protection. Journal of Security and Sustainability Issues, 8(2), 143-150. https://doi.org/10.9770/jssi.2018.8.2(2)

Xiang, D., Chen, J., Tripe, D., Zhang, N. (2018). Family firms, sustainable innovation and financing cost: Evidence from Chinese hitech small and medium-sized enterprises. Technological Forecasting and Social Change, In press, corrected proof, Available online 22 March 2018

Zemguliene J, Valukonis, M. (2018). Structured literature review on business process performance analysis and evaluation. Entrepreneurship and Sustainability Issues, 6(1), 226-252. https://doi.org/10.9770/jesi.2018.6.1(15) 
Inga SHAPOVALOVA, Doctor of Economics, Associate Professor, Head of the Department of Economics and Information Technology, Mykolaiv Interregional Institute for Human Development, Higher Education Establishment "Open International University of Human Development "Ukraine"

ORCID ID: orcid.org/0000-0003-1588-3910

Iryna BANYEVA, Doctor of Economics, Professor, Professor of the Subdepartment of Company Production and Innovative Activity Management, Mykolaiv National Agrarian University

ORCID: ID: orcid.org/0000-0001-7326-1461

Nataliia HUSARINA, Candidate of Economic Sciences, Associate Professor, Kherson National Technical University ORCID ID: orcid.org/0000-0003-3418-9422

Svitlana PETROVSKA, Ph.D., Associate Professor, National Aviation University

ORCID ID: orcid.org/0000-0001-6034-0224

Marharyta KRAVCHENKO, PhD of Economics, Associate Professor, National University of the State Fiscal Service ORCID ID: https://orcid.org/0000-003-4655-4950

Register for an ORCID ID:

https://orcid.org/register

This work is licensed under the Creative Commons Attribution International License (CC BY). http://creativecommons.org/licenses/by/4.0/ 